\title{
MALARIA IN HUMAITA COUNTY, STATE OF AMAZONAS, BRAZIL. XIX - EVALUATION OF CLINDAMYCIN FOR THE TREATMENT OF PATIENTS WITH PLASMODIUM FALCIPARUM INFECTION
}

\section{Domingos Alves Meira1, Paulo Camara Marques Perelra1, Jussara Marcondes-Machado1, Rinaido Poncio Mendes1, Benedito Barraviera1, José Antonio G. Pirola1, Maria Regina Cotrim Guimarāes 1 , Paulo Roberto Curl2 and Renato Pedro Rodrigues'.}

\begin{abstract}
A total of 207 patients with malaria caused by Plasmodium falciparum were submitted to 5 different treatment schedules with clindamycin from 1981 to 1984: A89 patients were treated intravenously and orally, or intramuscularly and orally with $20 \mathrm{mg} / \mathrm{kg} /$ day divided into two daily applications for 5 to 7 days; $B-40$ patients were treated orally with $20 \mathrm{mg} / \mathrm{kg} /$ day divided into two daily doses for 5 to 7 days; $\mathrm{C}-27 \mathrm{pa}$ tients were treated with $20 \mathrm{mg} / \mathrm{kg} /$ day intravenously or orally divided into two daily applications for 3 days; $D-16$ patients were treated orally and/or intravenously with a single daily dose of 20 to $40 \mathrm{mg} / \mathrm{kg} /$ day for 5 to 7 days; $E$ - 35 patients were treated orally with $5 \mathrm{mg} / \mathrm{kg} /$ day divided into two doses for 5 days. Patients were examined daily during treatment and reexamined on the 7 th $, 14 t \mathrm{~h}, 21$ st, $28 \mathrm{th}$ and 35 th day both clinically and parasitologically (blood test). Eighty three (40.1\%) had moderate or severe malaria, and $97(46.8 \%)$ had shown resistance to chloroquine or to the combination of sulfadoxin and pyrimethamine. The proportion of cured patients was higher than $95 \%$ among patients submitted to schedules $A$ and $B$. Side effects were only occasional and of low intensity. Three deaths occurred (1.4\%), two of them involving patients whose signs and symptoms were already very severe when treatment was started. Thus, clindamycin proved to be very useful in the treatment of patients with malaria caused by Plasmodium falciparum and we recommend schedule $A$ for moderate and severe cases and $B$ for initial cases.
\end{abstract}

Key-words: Malaria treatment. Plasmodium falciparum. Clindamycin.

Since the first report by Silva et $\mathrm{al}^{31}$ in 1961 of the occurrence of Plasmodium falciparum resistance to chloroquine in Brazil, this phenomenon has shown a tendency to increase ${ }^{2} 45$. The increase in number of resistant Plasmodium falciparum strains to multiple drugs has reopened the question of the need to reevaluate the use of antibiotics in the treatment of malaria ${ }^{10} 2527$. The search for new options in the treatment of severe malaria caused by Plasmodium falciparum has gained growing importance with the progressive increase of cases recorded since $1970^{15} 18$.

1. Departamento de Moléstias Infecciosas e Parasitárias, Dermatologia e Radiologia, Faculdade de Medicina, Campus de Botucatu - UNESP.

2. Departamento de Cirurgia, Faculdade de Medicina, Campus de Botucatu - UNESP.

Correspondence to: Domingos Alves Meira - Departamento de Moléstias Infecciosas e Parasitárias, Dermatologia e Radiologia - Faculdade de Medicina de Botucatu - UNESP Caixa Postal 522 - 18610 - Botucatu - São Paulo - Brasil. Recebido para publicação em 14/12/87
Among the antibiotics used, special attention has been given to halogenate lincomycin derivatives 1617262829 and to clindamycin 1378222428 , which have shown promise.

In a previous study ${ }^{24}$, we demonstrated the efficacy of clindamycin as the single antimalarial drug used in the treatment of patients infected with Plasmodium falciparum. However, several points concerning malaria treatment with clindamycin have not yet been fully elucidated. Among them, especially important are the slow elimination of parasitemia 372428 the repercussions of the severity of the disease and the relationship with patient origin ${ }^{21}$, i. e. whether or not the patient is from a natural endemic region.

The objective of the present study was to determine the best schedule of clindamycin treatment for the treatment of patients infected with Plasmodium falciparum considering patient origin, severity of the disease, previous resistance of the plasmodium to other antimalarial drugs, and the duration of parasitemia. 
Meira DA, Pereira PCM, Marcondes-Machado J, Mendes RP, Barraviera B, Pirola JAG, Guimarães MRC, Curi PR, Rodrigues RP. Malaria in Humaita county, State of Amazonas, Brazil. XIX-Evaluation of clindamycin for the treatment of patients with Plasmodium falciparum infection. Revista da Sociedade Brasileira de Medicina Tropical 21: 123-129, Jul-Set, 1988

\section{CASES AND METHODS}

Sixty one, 97, 42 and 7 patients infected with Plasmodium falciparum were studied in the summers of 1981, 1982 and 1983 and in the winter of 1984, respectively. From 1981 to 1983 , these patients were seen at the State of Amazonas Health Department Hospital and at the Outpatient Clinic of SUCAM, in Humaita, State of Amazonas, Brazil, and in 1984 at the "Presidente Medici" Hospital, State of Rondonia, Brazil. Etiologic diagnosis of malaria and parasitemia counts were performed by the classical method ${ }^{23}$. All patients were submitted to complete clinical examination including epidemiologic data, physical examination and laboratory tests, before and after treatment, using a standard file card. Laboratory tests included hemogram, urinalysis, feces parasitology, and electrocardiogram. Patients were classified according to severity of the disease, presence of associated disease, origin and previous plasmodium resistance to chloroquine and/or to treatment with combined sulfadoxin and pyrimethamine. The severity of the disease was determined by clinical and parasitologic parameters considering not only the intensity of asexual parasitemia, but also the presence or abscence of gametocytes $^{19} 20$. With respect to origin, patients were divided into two groups: Amazonians, i.e. subjects born in the Amazon Region, and non-Amazonians, i.e., migrants from other regions of the country who contracted the disease in Amazonia.

Table 1 shows the treatment schedules used for clindamycin. In schedules A, B and D, treatment lasted 7 days when important clinical manifestations still persisted or asexual parasitemia was positive on the $5^{\text {th }}$ day. In schedules A, C and D, clindamycin was diluted in $150 \mathrm{ml}$ of $5 \%$ glucose solution and administered intravenously dropwise for $\mathbf{3 0}$ minutes. In schedule $\mathbf{A}$, the oral route was usually utilized during the final period of treatment when the patient had improved and asexual parasitemia had decreased.
Table 2 shows patient distribution by age range and sex according to the treatment schedules used. One hundred and twenty six patients $(61.2 \%)$ were white and $81(39,8 \%)$ nonwhite. The professions linked to exposure to infection were predominant, i.e., $105(73.4 \%)$ of the 143 patients with a declared profession were laborers, rubber tree tappers, topographers and prospectors for gold and precious stones.

The roads that cross the region and which correspond to the areas of greatest transmission of malaria ${ }^{18}$ were reported as the probable site of contagion by 168 patients $(81.1 \%)$ who lived or worked there, while 18 patients $(8.7 \%)$ were infected in Rondonia and $21(10.2 \%)$ at indeterminate sites.

All patients were examinated daily and tested for parasitemia during treatment. These procedures were repeated up to the $7^{\text {th }}$ day in 34 patients, and in 170 of them were also performed on the $14^{\text {th }}(\mathrm{N}=54)$, $21^{\text {st }}(\mathrm{N}=77), 28^{\text {th }}(\mathrm{N}=34)$ and $35^{\text {th }}(\mathrm{N}=5)$ day. These tests were repeated up to the day of death in the 3 fatal cases.

Cure was considered to have occurred when remission of clinical manifestations was observed, when asexual parasitemia was negative during the 7 days following the beginning of treatment and continued to be negative on the occasion of delayed controls.

The possible side effects attribuable to treatment were observed.

\section{Statistical Analysis}

Data were analyzed statistically by the $\mathrm{X}^{2}$ test, by comparing the rates of success, and by the nonparametric test of Friedman ${ }^{11} 14$.

\section{RESULTS}

Analysis of the results showed a strong association between treatment schedule and age range $(\mathrm{p}<$

Table 1 - Distribution of 207 patients infected with Plasmodium falciparum according to the schedule of clindamycin treatment used

\begin{tabular}{crlccc}
\hline Schedule & $\begin{array}{c}\text { Duration } \\
\text { (days) }\end{array}$ & \multicolumn{1}{c}{ Route } & $\begin{array}{c}\text { Dose } \\
\mathrm{Mg} \mathrm{Kg}^{-1} \text { day }^{-1}\end{array}$ & $\begin{array}{c}\text { Interval } \\
\text { (hours) }\end{array}$ & $\begin{array}{c}\text { N. of } \\
\text { Patients }\end{array}$ \\
\hline A & $5-7$ & IV + oral, or IM* & 20 & 12 & 89 \\
B & $5-7$ & Oral & 20 & 12 & 40 \\
C & 3 & Oral or IV** & 20 & 12 & 27 \\
D & $5-7$ & Oral and/or IV & 20 or $40^{* * * *}$ & 24 & 16 \\
E & 5 & Oral & 5 & 12 & 35 \\
\hline
\end{tabular}

\footnotetext{
* Seven patients were treated I.M.;

** 20 patients were treated with chloroquine combined with clindamycin at the dose of $10 \mathrm{mg} / \mathrm{kg}, \mathrm{IM}$, on the $1^{\text {st }}$ day and at the dose of $7 \mathrm{mg} \mathrm{kg}{ }^{-1}$ day $^{-1}$ on the $2^{\text {nd }}$ and $3^{\text {rd }}$ days by the oral route at 12 intervals;

*** 3 patients received $40 \mathrm{mg} \mathrm{kg}^{-1}$ day $^{-1}$ IV.
} 
Meira DA, Pereira PCM, Marcondes-Machado J, Mendes RP, Barraviera B, Pirola JAG, Guimarães MRC, Curi PR, Rodrigues RP. Malaria in Humaita county, State of Amazonas, Brazil. XIX-Evaluation of clindamycin for the treatment of patients with Plasmodium falciparum infection. Revista da Sociedade Brasileira de Medicina Tropical 21: 123-129, Jul-Set, 1988

Table 2 - Distribution of patients with malaria caused by Plasmodium falciparum according to age range sex and treatment schedule

\begin{tabular}{|c|c|c|c|c|c|c|}
\hline \multirow{2}{*}{$\begin{array}{l}\text { Treatment } \\
\text { Schedule }\end{array}$} & \multicolumn{3}{|c|}{$\begin{array}{l}\text { Age Range } \\
\text { (years) }\end{array}$} & \multirow[t]{2}{*}{ Total } & \multicolumn{2}{|c|}{ Sex } \\
\hline & $0 \geq 5$ & $5 \geq 15$ & $1>15$ & & Males & Females \\
\hline A & $6(0.07)$ & $17(0.19)$ & $66(0.74)$ & 89 & $75(0.84)$ & $14(0.16)$ \\
\hline B & $12(0.30)$ & $14(0.35)$ & $14(0.35)$ & 40 & $33(0.83)$ & $7(0.17)$ \\
\hline $\mathrm{C}$ & $0 .(0.00)$ & $0(0.00)$ & $27(1.00)$ & 27 & $24(0.89)$ & $3(0.11)$ \\
\hline $\mathrm{D}$ & $9(0.56)$ & $5(0.31)$ & $2(0.13)$ & 67 & $7(0.44)$ & $9(0.56)$ \\
\hline $\mathrm{E}$ & $1(0.03)$ & $5(0.14)$ & $29(0.83)$ & 35 & $29(0.83)$ & $6(0.17)$ \\
\hline Total & $28(0.13)$ & $41(0.20)$ & $138(0.67)$ & 207 & $168(0.81)$ & $39(0.19)$ \\
\hline
\end{tabular}

(Age Range) $x_{8}^{2}=\underset{c=0.59}{70.629} p<0.001$

(Sex) $\quad \mathrm{X}_{4}^{2}=\underset{c=0.28}{16.416} \mathrm{p}<0.01$

$0.001 ; C=0.59$ ), with patients older than 15 years predominating in schedules $A$ and $E$. In schedule $B$, all age ranges were equally distributed. A11 patients in schedule $\mathrm{C}$ were 15 years old or more. Finally, children predominated in schedule $\mathbf{D}$.

The association between patient sex and treatment schedule was weak, since males predominated in all schedules except schedule $D$, in which sex distribution was identical.

Table 3 shows that patients classified by clindamycin treatment schedule and by previous resistance of Plasmodium falciparum to classical antimalarial drugs, i. e., to chloroquine and to the combination of sulfadoxine and pyrimethamine did not differ in distribution among the various treatment schedules. It should be emphasized that 97 (46.8\%) patients were infected with a resistant plasmodium strain, 81 of them $(39.1 \%)$ at the $R_{I}$ level and $16(7.7 \%)$ at the $R_{I I}$ and $\mathbf{R}_{\mathrm{III}}$ levels.

Analysis of the results presented in Table 4 reveals that patient distribution by severity of the disease differed among the various treatment schedules, with most moderately and seriously ill patients being included in schedules A, B and D. In schedule A, 5 patients had the cerebral form of the disease, 1 had acute renal failure, 2 showed peripheral failure and very intensive malarial attacks, and 3 had jaundice. Among the patients in schedule B there was a onemonth old baby, who probably had the congenital form of the disease. Among the patients in schedule $\mathrm{D}$ there was a large proportion of subjects with the moderate or severe form, including one with the cerebral form and another with jaundice, even though this group consisted of a small number of patients. The highest proportion of benign forms ocurred among patients in schedule E.

Table 5 shows distribution by region of origin with respect to the result obtained with each schedule of clindamycin treatment. No difference in patient proportion in each of the schedules used was detected when Amazonians were compared with individuals coming from other regions of the country. Analysis of the results also showed that the proportion of cured subjects was statistically higher in schedules A and B. It should be pointed out that 86 of 89 patients (96.6\%) were cured in schedule $A$, and 39 of $40(97.5 \%)$ were cured in schedule $B$. The proportion of cured subjects was lower in the remaining schedules, i.e. $80.0 \%$ for $E$, $70.4 \%$ for $C$ and $50.0 \%$ for $D$.

The occurrence of negative asexual parasitemia differed when the various clindamycin schedules were compared. Statistically significant differences were observed only on the occasion of the delayed controls performed between the $14^{\text {th }}$ and $35^{\text {th }}$ days $(H=38.241$; $\mathrm{p}<0.001$ ) when parasitemia was found to be negative only among patients submitted to treatment schedules A and B. Positive asexual parasitemia was detected in growing proportions among patients submitted to treatment schedules $\mathrm{E}, \mathrm{C}$ and $\mathrm{D}$, indicating that treatment failure occurred in these groups.

Eight of the 27 patients who were not cured by the treatment received were submitted to further treatment with clindamycin. Three of them had been submitted to schedule C, 2 to schedule $E$ and 1 to schedule B. After further treatment, 4 patients were cured by schedule A, 2 by schedule B, and one by schedule $D$. There was only one case of treatment failure concerning a patient resubmitted to treatment schedule D.

Side effects attributable to treatment with clindamycin were seldom observed: diarrhea in 3 patients submitted to schedule B and in one submitted to 
Meira DA, Pereira PCM, Marcondes-Machado $J$, Mendes RP, Barraviera B, Pirola JAG, Guimaräes MRC, Curi PR, Rodrigues RP. Malaria in Humaita county, State of Amazonas, Brazil. XIX-Evaluation of clindamycin for the treatment of patients with Plasmodium falciparum infection. Revista da Sociedade Brasileira de Medicina Tropical 21: 123-129, Jul-Set, 1988

Table 3 -Patient distribution according to schedule of treatment with clindamycin and previous resistance to classical antimalarial drugs.

\begin{tabular}{|c|c|c|c|c|c|}
\hline \multirow{2}{*}{$\begin{array}{l}\text { Treatment } \\
\text { Schedule }\end{array}$} & \multicolumn{2}{|c|}{ Previous Resistance } & \multirow[b]{2}{*}{ Other* } & \multirow[b]{2}{*}{ Total } & \multirow[b]{2}{*}{$\mathrm{R}_{\mathrm{I}}+\mathrm{R}_{\mathrm{II}}+\mathrm{R}_{\mathrm{III}}$} \\
\hline & $\mathrm{R}_{\mathrm{I}}$ & $\mathrm{R}_{\mathrm{II}}+\mathrm{R}_{\mathrm{III}}$ & & & \\
\hline $\mathrm{A}$ & $32(34.83)$ & $9(6.88)$ & $48(46.29)$ & 89 & 0.46 \\
\hline B & $16(15.65)$ & $1(3.09)$ & $23(21.26)$ & 40 & 0.43 \\
\hline $\mathrm{C}$ & $10(10.57)$ & $2(2.09)$ & $15(14.34)$ & 27 & 0.44 \\
\hline $\mathrm{D}$ & $9(6.26)$ & $2(1.24)$ & $5(8.50)$ & 16 & 0.69 \\
\hline $\mathrm{E}$ & $14(13.70)$ & $2(2.71)$ & $19(18.59)$ & 35 & 0.46 \\
\hline Total & 81 & 16 & 110 & 207 & 0.47 \\
\hline
\end{tabular}

* Sensitive or not treated previously $p>0.50 \quad x_{8}^{2}=5.831$

Table 4 - Patient distribution according to schedule of treatment with clindamycin and severity of the clinical form of the disease

\begin{tabular}{|c|c|c|c|c|}
\hline \multirow{2}{*}{$\begin{array}{l}\text { Treatment } \\
\text { Schedule }\end{array}$} & \multicolumn{2}{|c|}{ Clinical form } & \multirow{2}{*}{ Total } & \multirow{2}{*}{$\begin{array}{l}\text { Proportion of } \\
\text { Moderate }+ \text { Sever }\end{array}$} \\
\hline & Mild & Moderate + Severe & & \\
\hline $\mathrm{A}$ & $40(53.31)$ & $49(35.69)$ & 89 & 0.55 \\
\hline B & $28(23.96)$ & $12(16.04)$ & 40 & 0.30 \\
\hline $\mathrm{C}$ & $20(16.17)$ & 710.83 ) & 27 & 0.26 \\
\hline $\mathrm{D}$ & $7(9.58)$ & $9(6.42)$ & 16 & 0.56 \\
\hline $\mathrm{E}$ & $29(20.97)$ & $6(14.03)$ & 35 & 0.17 \\
\hline Total & 124 & 83 & 207 & \\
\hline
\end{tabular}

Table 5 - Patient distribution according to origin and result of treatment with the different clindamycin schedules

\begin{tabular}{|c|c|c|c|c|c|c|c|}
\hline \multirow{3}{*}{$\begin{array}{l}\text { Treatment } \\
\text { Schedule }\end{array}$} & \multicolumn{3}{|c|}{ Amazonians (Am) } & \multicolumn{3}{|c|}{ Non-Amazoninans (NAm) } & \multirow{3}{*}{$\begin{array}{c}\text { Genera } \\
\text { Total }\end{array}$} \\
\hline & \multirow[b]{2}{*}{ Total } & \multicolumn{2}{|c|}{ Cured } & \multirow[b]{2}{*}{ Total } & \multicolumn{2}{|c|}{ Cured } & \\
\hline & & No & Proportion & & No & Proportion & \\
\hline A & 48 & 47 & 0.9792 & 41 & 39 & 0.9512 & 89 \\
\hline B & 33 & 32 & 0.9697 & 7 & 7 & 1.0000 & 40 \\
\hline C & 14 & 9 & 0.6429 & 13 & 10 & 0.7692 & 27 \\
\hline D & 11 & 5 & 0.4545 & 5 & 3 & 0.60000 & 16 \\
\hline $\mathrm{E}$ & 21 & 16 & 0.7619 & 14 & 12 & 0.8571 & 35 \\
\hline Total & 127 & 109 & 0.8583 & 80 & 71 & 0.8875 & 207 \\
\hline
\end{tabular}

Proportion of cured:

Am $\times$ NAm

$\mathrm{X}^{2}=1.378 ; \mathrm{p}>0.80$

$\mathrm{Am}=\mathrm{NAm}$

A $\times$ B $\times$ C $\times$ D $\times$ E

$\mathrm{X}^{2}=38.571 ; \mathrm{p}<0.001$

$(\mathrm{A}=\mathrm{B})>\mathrm{E}>\mathrm{C}>\mathrm{D}$ 
Meira DA, Pereira PCM, Marcondes-Machado J, Mendes RP, Barraviera B, Pirola JAG, Guimaräes MRC, Curi PR, Rodrigues RP. Malaria in Humaita county, State of Amazonas, Brazil. XIX-Evaluation of clindamycin for the treatment of patients with Plasmodium falciparum infection. Revista da Sociedade Brasileira de Medicina Tropical 21: 123-129, Jul-Set, 1988

schedule $C$; vomiting in 2 patients treated with schedule $B$, and pain at the site of injection in 2 submitted to schedule $A$ by the intramuscular route. In none of these cases, however was it necessary to discontinue treatment.

Three patients $(1.4 \%)$ died during treatment. Two of them were in serious condition at the time of diagnosis. Of these, one was a 4year old Amazonian child who had been ill for 3 days and had the cerebral form of fulminating evolution. This child had suffered convulsions lasting 7 hours before treatment was started and was in a coma. She was submitted to schedule D for 2 days, but showed no improvement before she died. The second was a 31-year old nonAmazonian male who had become ill 6 days before treatment was started and who was in acute renal failure. This patient was submitted to schedule A for 5 days. Even though asexual parasitemia was appreciably reduced by clindamycin, this patient developed acute renal failure and anuria up to his death which occurred on the $5^{\text {th }}$ day of treatment. It was not possible to treat his acute renal faillure because of the lack of facilities for dialysis treatment at Humaita at the time, and because transfer to another hospital in Porto Velho or in Manaus could not be arranged. The third was a 2-year old Amazonian child who had suffered a previous malarial attack caused by Plasmodium falciparum resistant $\left(\mathbf{R}_{\mathbf{I}}\right)$ to chloroquine and who showed the moderate form of the disease at the time of diagnosis. This patient was initially treated by schedule B. On the third day he became worse and fell into a coma. The clindamycin route was changed to the intravenous mode (schedule $\mathrm{A}$ ) but the child continued in a coma and died on the fifth day.

\section{DISCUSSION}

Clindamycin (7-(S)-chloro-7-deoxylincomycin) has been extensively studied as an antibiotic indicated for the treatment of serious infections. This drug is active against Gram-positive aerobic bacteria and very active against Gram-positive and negative anaerobic bacteria. Clindamycin inhibits bacterial protein synthesis and has both a bactericidal and bacteriostatic action. Experimental and clinical studies have demonstrated its activity in the treatment of human and animal malaria caused by resistant strains of Plasmodium falciparum 1378916172224262829 .

The present search for an ideal schedule for the treatment of malaria caused by Plasmodium falciparum using clindamycin as the sole antimalarial drug was motivated by the effectiveness of this treatment, taking into account some still no fully elucidated factors such as patient origin, severity of clinical form, previous resistance of the plasmodium to classical antimalarial drugs, and the time needed for asexual parasitemia to become negative. The treatment schedules used here differed in duration, administration route, dose, and interval between doses. In this respect, schedule B differed from schedule A only in terms of administration route, which was exclusively oral in $\mathbf{B}$.

Schedule $\mathrm{C}$ had the longest interval between doses, and schedule $\mathrm{E}$ the shortest dose. Thus, the patients were not assigned to a treatment schedule at random but on the basis of criteria including severity of clinical form, absence of as exual parasitemia ${ }^{1920}$, and the easier administration of the drug to children by the oral route. This may explain the variation observed among the various treatment schedules and some preliminary factors such as age group, sex and severity of the disease. However, there was no difference among treatment groups in terms of previous resistance to classical antimalarial drugs since the proportions of the different levels of resistance were the same in each group. The proportion of previous resistance to classical antimalarial drugs was higher than that reported by Alecrim et $\mathrm{al}^{3}$ and Rivera et $\mathrm{al}^{28}$.

Schedule $A$ included the largest number of patients with the severe form of the disease and with higher asexual parasitemia and therefore was the schedule of longest duration, of shortest interval between doses and of most prolonged intravenous clindamycin administration. Schedules D and B followed $\mathrm{A}$ in terms of proportion of severe forms of the disease, while schedule $E$ included the largest number of benign cases. Indeed, the lowest clindamycin dose was used in schedule $\mathrm{E}$.

The same proportion of therapeutic efficacy was observed among non-Amazonians and Amazonians in all treatment schedules used. Thus, clindamycin did not perform differently with respect to patient origin, though a difference may exist between patient origin and predisposition to malaria ${ }^{21}$. The highest cure rates $(>95.0 \%)$ occurred among patients treated with schedules $\mathbf{A}$ and $\mathbf{B}$, and it should be emphasized that these grups included most of the patients with severe forms of malaria. These results agree with those reported by Alecrim et $a^{1}$, Cabrera et $\mathrm{al}^{7}$ and Rivera et $\mathrm{al}^{28}$, who used intravenously administered clindamycin for 5 to 7 days at the dose of $20 \mathrm{mg} / \mathrm{kg} /$ day with 12-hour intervals between doses.

Patients treated with schedule $\mathrm{E}$ had lower cure rates $(80.0 \%)$, but the lowest rates were observed among those on schedules $\mathrm{C}(70.3 \%)$ and $\mathrm{D}(50.0 \%)$.

It should be pointed out that asexual parasitemia was negative on the occasion of delayed controls only in patients treated with schedules A or B.

These results indicate the superiority of schedules $A$ and $B$ and suggest that clindamycin should not be used for a period of less than 5 days or at intervals between doses longer than 12 hours, or at doses lower than $20 \mathrm{mg} / \mathrm{kg} /$ day. 
Meira DA, Pereira PCM, Marcondes-Machado J, Mendes RP, Barraviera B, Pirola JAG, Guimarães MRC, Curi PR, Rodrigues RP. Malaria in Humaita county, State of Amazonas, Brazil. XIX-Evaluation of clindamycin for the treatment of patients with Plasmodium falciparum infection. Revista da Sociedade Brasileira de Medicina Tropical 21: 123-129, Jul-Set, 1988

Clindamycin seems to act on Plasmodium falciparum by inhibiting mitochondrial function or synthesis ${ }^{12} 13$. On the other hand, in vitro results reported by Seaberg et $a^{30}$ suggest that the inhibition of Plasmodium falciparum growth depends on time of parasite exposure to clindamycin, so that for 90.0 to 95.0\% inhibition to occur, 72 hours of exposure to the drug are needed. In the present study the duration of treatment in the most effective schedules (A and B) agrees with data reported by Seaberg et $\mathrm{al}^{30}$ and should not be considered as a factor discouraging the choice of this antibiotic.

Side effects occurred only occasionally and were of low intensity, so that treatment did not have to be discontinued in any case, as also reported by other authors ${ }^{3} 728$. None of the patients treated with clindamycin showed symptoms of the pseudomembranous colitis associated with Clostridium difficile ${ }^{6}$.

Even though the three fatal cases were reported as treatment failures for data analysis purpose, it should be pointed out that two of these patients were started on clindamycin when their condition was already very serious. One of them was in a coma and had been suffering generalized convulsions for more than 7 hours, and another showed acute renal failure and anuria, with local conditions not permitting dialysis. Both patients were first seen when they were in a pre-agonic and irreversible condition.

Finally, the present results permit us to suggest that clindamycin can be indicated for the treatment of patients with malaria caused by Plasmodium falciparum resistant to classical antimalarial drugs. The following two treatment sehedules are recommended: $20 \mathrm{mg} / \mathrm{kg} /$ day oral clindamycin divided into two doses at 12-hour intervals for 5 to 7 days for benign cases, and $20 \mathrm{mg} / \mathrm{kg} /$ day in two daily applications at 12-hour intervals by the intravenous or intramuscular route for 5 to 7 days for moderate and severe cases.

\section{RESUMO}

De 1981 a 1984, 207 doentes com malária, causada pelo Plasmodium falciparum, foram tratados com 5 esquemas de clindamicina: $\mathrm{A}-89$ doente tratados com $20 \mathrm{mg} / \mathrm{kg} / \mathrm{dia}$, pelas vias endovenosa e oral, ou intramuscular e oral, em duas aplicações diárias, durante 5 a 7 dias; B - 40 doentes tratados com 20 $\mathrm{mg} / \mathrm{kg} / \mathrm{dia}$, por via oral, em duas tomadas diárias, durante 5 a 7 dias; $\mathrm{C}-27$ doentes tratados com 20 $\mathrm{mg} / \mathrm{kg} / \mathrm{dia}$, por via oral ou endovenosa, em duas tomadas diárias, durante 3 dias; D - 16 doentes tratados com 20 a $40 \mathrm{mg} / \mathrm{kg} / \mathrm{dia}$, por vias oral, e/ou, endovenosa, em uma única dose diária, durante 5 a 7 dias; $\mathrm{E}-35$ doentes tratados com $5 \mathrm{mg} / \mathrm{kg} / \mathrm{dia}$, por via oral, em duas doses diárias, durante 5 dias. Os doentes foram examinados, diariamente, durante o tratamento e reexaminados no $7 \circ^{\circ}, 14 \%, 28 \circ^{\circ}$ e $35 \circ^{\circ}$ dias, tanto pelo exame clínico, quanto pelo parasitológico de sangue. Oitenta e três $(40,1 \%)$ tinham malária moderada ou grave e $97(46,8 \%)$ tinham apresentado resistência à cloroquina, ou à associação sulfadoxina e pirimetamina. Os resultados mostraram que a proporção de curados foi superior a $95 \%$ nos doentes tratados pelos esquemas A e B. Os efeitos colaterais observados foram ocasionais e de pequena intensidade. Houve três casos de óbito $(1,4 \%)$, dois dos quais atendidos desde o início com quadro muito grave. A clindamicina. portanto, mostrou ser muito útil no tratamento de doentes com malária causada pelo Plasmodium falciparum; recomenda-se o esquema A para os casos moderados e o B para os benignos.

Palavras-chaves: Tratamento da malária. Plasmodium falciparum. Clindamicina.

\section{ACKNOWLEDGEMENTS}

We wish to thank "Fundação Projeto Rondon", the Directory of the Advanced Campus, and Humaita SUCAM.

\section{REFERENCES}

1. Alecrim MG, Dourado $\mathbf{H}$, Alecrim W, Albuquerque $\mathrm{BC}$, Wanssa $\mathrm{E}$, Wanssa MC Tratamento da malaria $(P$. falciparum) com clindamicina. Revista do Instituto de Medicina Tropical de São Paulo 23: 86-91, 1981.

2. Alecrim MGC, Alecrim WD, Albuquerque BC de, Dourado HV, Wanssa MC. Resistência "in vivo" do Plasmodium falciparum à associação sulfametoxazol mais trimetoprin na Amazônia Brasileira. Revista do Instituto de Medicina Tropical de São Paulo 24: (Supl. 6): 48-51, 1982.

3. Alecrim WD, Albuquerque BC, Alecrim MGC, Dourado $\mathrm{H}$. Tratamento da malária $(\boldsymbol{P}$. falciparum) com clindamicina. II - Esquema posológico em cinco dias. Revista do Instituto de Medicina Tropical de São Paulo 24 (Supl. 6): 40-43, 1982.

4. Alecrim WD, Dourado H, Alecrim M das G, Passos LF, Wanssa E, Albuquerque B. Resistência "in vivo" do Plasmodium falciparum à associação sulfadoxina mais pirimetamina, a nivel de R III, no Amazonas, Brasil. Revista do Instituto de Medicina Tropical de São Paulo 24(Supl. 6): 52-53, 1982.

5. Almeida Neto JC, Oliveira GSC, Sampaio JAA. Resistência do $P$. falciparum à associação sulfamídicos na região Centro-Oeste do Brasil. Dados referentes ao estudo de 104 pacientes. Revista de Patologia Tropical de Goiás 3: 385-393, 1972.

6. Boriello SP. Clostridium difficile and gut disease. In: CS Goode (ed) Microbes and Infectious of the gut. Scientific Publications. Date Late 327-346, 1983.

7. Cabrera BD, Rivera DG, Lara NT. Study on clindamycin in the treatment of falciparum malaria. Revista do Instituto de Medicina Tropical de São Paulo 24: (Supl. 6): 62-69, 1982. 
8. Clyde DF, Gilmar RH, Mc Carthy VC. Antimalarial effects of clindamycin in man. American Journal of Tropical Medicine and Hygiene 24: 369-370, 1975.

9. DeHaan RM, Metzler CM, Schellenberg D, Vandenbosh WD. Pharmacockinetic studies of clindamycin phosphate. Journal of Clinical Pharmacology 13: 190$209,1973$.

10. Dourado $\mathbf{H}$. Terapêutica da malária com minociclina. Revista Brasileira de Clínica e Terapêutica 2: 10-12, 1973.

11. Fleiss JL. Statistical methods for rates and proportions. John Wiley \& Sons, New York, 1973.

12. Geary TG, Divo AA, Jensen JB. An in vitro assay system for the identification of potential antimalarial drugs. Journal of Parasitology 69: 577-583, 1983.

13. Geary TG, Jensen JB. Effects of antibiotics on Plasmodium falciparum in vitro. American Journal of Tropical Medicine and Hygiene 32:221-225, 1983.

14. Hollander M, Wolfe DA. Nonparametric Statistical Methods. John Wiley \& Sons, New York, 1973.

15. IES - Informações Epidemiológicas SUCAM. Casos notificados de malária por área de erradicação a longo e curto prazo e por unidade. No 26, dezembro, 1984.

16. Lewis C. Antiplasmodial activity of halogenated lincomycin analogues in Plasmodium falciparum infected mice. In: Antimicrobial Agents and Chemotherapy, p. 537-542, 1967.

17. Lewis C. Antiplasmodial activity of 7-halogenated lincomycins. The Journal of Parasitology 54:169-170, 1968.

18. Meira DA, Curi PR, Barraviera B. Malaria in Humaita county, Amazonas State, Brazil. XXIX - Some comparative epidemiologic aspects in 1976,1979 and 1983. In: Proceedings of IV Japan-Brazil Symposium on Science and Technology São Paulo 2: 136-143, 1984.

19. Meira DA, Curi PR, Marcondes J, Matsuoka ES, Favrin MA, E1 - Khoury AB, Motta NGS. Malaria at Humaita County, Amazonas State, Brazil. XVII Immune response in patients with Plasmodium falciparum according to gametocytes. Revista do Instituto de Medicina Tropical de São Paulo 27:229-237, 1985.

20. Meira DA, Marcondes J, Barraviera B, Pereira PCM, Rui P, Cury PR. Malaria at Humaita County, Amazonas State, Brazil. XVI - Gametocytes and lymphocytes studied in patients with Plasmodium falciparum. Revista do Instituto de Medicina Tropical de São Paulo 24:(Supl. 6): 32-39, 1982.

21. Meira DA, Pellegrino Júnior J, Marcondes Machado J, Tsuji K, Matsuoka ES, Haida E, El Khoury AB.
Frequency of human leukocyte antigen (HLA) in patients with malaria and in the general population of Humaita county, Amazonas State, Brasil, Revista da Sociedade Brasileira de Medicina Tropical 20: 153-158, 1987.

22. Miller LH, Glew RH. Wyler DJ, Howard WA, Collins WE, Contacos PG, Neva FA. Evaluation of clindamycin in combination with quinine against multi drugresistant strains of Plasmodium falciparum. American Journal of Tropical Medicine and Hygiene 23: 565-569, 1974

23. OPAS - Manual de Diagnóstico Microscópico da Malária. Publicação Cientifica n̊ 276, p. 109, 1975.

24. Pereira PCM, Marcondes J, Barraviera B, Meira DA, Mendes RP, Vadileti C, Sogayar R, Rui P. Malária no município de Humaitá, Estado do Amazonas. XIII Uso da clindamicina no tratamento de doentes com infecção causada pelo Plasmodium falciparum. Revista do Instituto de Medicina Tropical de São Paulo 24: (Supl. 6): 16-23, 1982.

25. Peters W. Chemotherapy of malaria. In: Julius $\mathbf{P}$. Kreier. (ed) Malaria. Vol. 1, Academic Press, p. 145283, 1980.

26. Powers KG, Jacob RL. Activity of two chlorinated lincomycin analogues against chloroquine resistent falciparum malaria in owl monkeys. In: Antimicrobial Agents and Chemotherapy 49-53, 1972.

27. Rieckmann KH, Powell RD, McNamara JV, Willerson Jr D, Kass L, Frischer H, Carson PE. Effects of tetracycline against chloroquine-resistant and chloroquine sensitive Plasmodium falciparum. American Journal of Tropical Medicine and Hygiene 20:81 1-815, 1971.

28. Rivera DG, Cabrera, BD, Lara NT. Treatment of falciparum malaria with clindamycin. Revista do Instituto de Medicina Tropical de São Paulo 24 (Supl. 6): 70-75, 1982.

29. Schimidt LH, Harrison J, Ellison R, Worcester P. The activities of chlorinated lincomycin derivatives against infections with Plasmodium cynomolgi in Macaca mullatta. American journal of Tropical Medicine and Hygiene 19: 1-11, 1970.

30. Seaberg LS, Parquette AR, Gluzman IY, Phillips-Jr. GW, Brodasky TF, Krogstad DJ. Clindamycin activity against chloroquine resistant Plasmodium falciparum. Journal of Infections Diseases 150: 904-91 1, 1984.

31. Silva JR, Lopes PFA, Ferreira LF, Morteo R, Naveira JB. Resistência do $P$. falciparum à ação da cloroquina. Nota prévia. O Hospital 60:581-594, 1961. 